\title{
Persia, the Land of Shiite Faith: The Migration of Imam Ahl al-Bayt and the Encounter between Two Belief Systems in Persia
}

\author{
Fatemeh Sadat Alavi Aliabadi ${ }^{1 *}$, Sayed Alireza Vasei ${ }^{2}$ \\ 1 Mustafa International University, Islamic Republic of Iran; e-mail: f_alavi@miu.ac.ir \\ 2 Islamic Sciences and Culture Academy, Islamic Republic of Iran; e-mail: a.vasei@isca.ac.ir \\ * Correspondence
}

Received: 2021-06-12; Accepted: 2021-07-31; Published: 2021-08-12

\begin{abstract}
This article attempts to trace the fundamental role of early Persian beliefs, Zoroastrians, to the decision of Ahl al-Bayt's choice to migrate to Persia (Iran). This research is based on the fact that there are many places for pilgrimage to imams in Iran. Specifically, this research investigates the similarity of several concepts in both religions, Zoroaster and Islam, regarding the teaching in the principle of God (Ilahiyyah), the principle of life after death (eschatology), and the principle of justice and morals of the religion embraced before Islam in Persia. Several studies have also reported on the distortions, opposition, and the consequences of encountering the two beliefs for the first time between Persian beliefs and Islamic teachings. This study employs a qualitative method with historical analysis and literature study along with relevant information of the study. This article also uses the theory of migration and identity to see the interconnectedness of religion in the migration context. The results of this study show the factors that the Persians are interested in accepting and understanding the teachings of Islam. Those are: first, the emotional closeness of beliefs and moral values between Muslims and Zoroastrians (Magi); Second, the inclusive nature of Islam; third, the absence of racial, gender, and status discrimination in Islamic teachings. The descendants of imams Ahl al-Bayt of the Prophet Muhammad SAW continued the prophet's preaching and the Imams in expanding the spread of Islamic teachings to various regions. During this expansion process, they found Iran as the most secure, and suitable region to accept the presence and teaching of Islam especially the Shiite sect. Therefore, they decided to migrate to Iran, and until now Iran is known as a Shiite country.
\end{abstract}

Keywords: Ahl al-Bayt; eschatology; God; Imam; migration; Persia.

Abstrak: Artikel ini berusaha untuk menelusuri peran dasar keyakinan orang Persia awal (Zoroaster) dengan keputusan Ahl al-Bayt memilih untuk bermigrasi ke Persia (Iran). Penelitian ini didasarkan pada banyaknya tempat-tempat berziarah di Iran yang memiliki keterkaitan dengan para Imam di Iran. Penelitian ini berusaha menelusuri beberapa kesamaan dalam beberapa ajaran antara ajaran Zoroaster dengan ajaran-ajaran Islam sehingga Ahl al-Bayt memutuskan untuk bermigrasi ke Persia. Kesamaan ajaran agama yang akan dikaji yakni pada tiga aspek yaitu: prinsip-prinsip ketuhanan (ilahiyyah), prinsip kehidupan setelah kematian (eskatologis), prinsip keadilan dan moral. Beberapa penelitian juga menunjukkan tentang distorsi, penentangan dan akibat dari perjumpaan dua keyakinan tersebut untuk pertama kalinya antara keyakinan orang-orang Persia dan ajaran-ajaran Islam. Penelitian ini menggunakan metode kualitatif dengan analisis sejarah dan studi kepustakaan serta informasi-informasi yang relevan dengan topik kajian. Penelitian ini juga menggunakan teori migrasi dan identitas untuk melihat keterkaitan antara migrasi dan agama pada konteksnya. Hasil penelitian ini menunjukkan tentang faktor-faktor yang membuat ketertarikan orang-orang Persia untuk menerima dan memahami ajaran Islam. Di antaranya: pertama, adanya kedekatan emosional tentang keyakinan dan nilai-nilai moral antara pemeluk Islam dan Zoroaster (Majusi). Kedua, inklusifitas Islam sebagai agama. Dan, ketiga, tidak adanya diskriminasi ras, gender, dan status dalam 
ajaran Islam. Para keturunan Imam dari Ahl al-Bayt Nabi melanjutkan dakwah Nabi dan para Imam dalam memperluas penyebaran ajaran Islamnya ke berbagai wilayah. Dalam proses penyebaran tersebut, mereka menemukan Iran sebagai kawasan paling siap untuk menerima kehadiran dan dakwah Islam, karena itu mereka bermigrasi ke Iran, dan sampai sekarang Iran dikenal sebagai negara penganut Syiah.

Kata Kunci: Ahl al-Bayt; eskatologi; Imam; imigrasi/hijrah; Iran; ketuhanan.

\section{Introduction}

The great nation of Persia, along with its culture and civilisation for thousand years, has become the birthplace of many religions and cultures. The last and the most embraced religion in Persia is Islam. For more than fourteen centuries, Islam has occupied both the material and spiritual dimensions of the Persians. Until now, it remains the majority religion of Persian, which was later well-known as Iran. Although opposed to the domination of the Arabs at the beginning of the conquest, the Persians gradually came to know the teachings of Islam. Moreover, they also interacted with Islamic religious leaders, especially Imam Ali ibn Abi Thalib when he directed his government to Persia. Besides, the presence of Imam Ali ar-Ridha, the eighth Imam, in Khurasan has also enriched the rapid development of Shiite sects in Persia in enlivening spaces of study and interfaith dialogue.

Persia as the ancestor of the most ancient human civilisation accepted the last celestial religion and became a place of refuge and safety for the descendants of the Prophet Muhammad saw. In this regard, Ibn Thabathabai, one of the authors in the fifth century Hijri and the author of the book Muntaqilah alThalibiyyah, has mentioned that there are about three hundred and fifty cities, villages, and hamlets that the descendants of the Imams of the Ahl al-Bayt of the Prophet had ever visited and lived in (Tabataba'i, 2009). As mentioned in this book and similar books in the first five centuries $\mathrm{AH}$, there were more descendants of the emigrating Imams from the Ahl al-Bayt of the Prophet which determined and chose Persia as the most appropriate place to migrate. Although in this book, the author did not mention the exact number and the descendants' names of them, the historical fact is documented.

Today, there are many graves and pilgrimage places associated with the descendants of the Imam from the Ahl al-Bayt of the Prophet in Iran. Each of their lineage and genealogy is connected to the Ahl al-Bayt of the Prophet. The question is why are there so many graves and pilgrimage places associated with the descendants of the Imam from the Ahl al-Bayt of the Prophet in Iran? Several works show that one and the most important factors associated with the migration of Ahl al-Bayt to Persia was their security. Iran was far from the reach of the Umayyad and Abbasid rulers who victimised the descendant of Ahl al-Bayt at that time, and it also provided living facilities such as a nice climate.

This article attempts to investigate a deeper and more comprehensive answer than that of the previous studies mentioned regarding the decision of Ahl al-Bayt to migrate to Persia. This article argues that apart from security and living facilities reasons, Ahl al-Bayt chose Persia was also for the fact that Persia is a platform of belief and morality. Thus, this study focuses on the analysis of the belief system of the old Persia that attracted the descendants of the Imam from the Ahl al-Bayt of the Prophet to migrate to Persia. It is one of the important issues in the Islamic-Iranian civilisation that so far has received less attention. Therefore, there are limited books or scientific research articles found related to this issue. Thus, this research is important to conduct.

Historically, the migration of the descendants of the Imams from the Ahl al-Bayt of the Prophet to Iran occurred at the end of the first century AH. It continued throughout the era of the Twelve Imams and reached its peak in the third century AH. According to historians and scholars, in the first centuries of Islam, Muslims in Persia were not the majority. However, adherents of other religions, especially Zoroaster (Magi) constitute the majority in Iran (Zarrīnkūb, 1993). At that time, the Sunni in Iran had more adherents than the Shiite, as it is known that the compilers of the books of Sunni hadith were all Iranians (Nasr \& Mutahhari, 1975).

The most important thing to know is the attractiveness of Persia to the descendants of the Prophet Muhammad. The emotional closeness of the Persians with the Prophet Muhammad and his 
descendants of Ahl al-Bayt becomes one of the main factors of their presence in Persia. The roots of the closeness of the two directions can be traced to the realm of ideological similarities of the two Celestial religions: Islam and Zoroaster (Magi).

The Qur'an considers Zoroaster (Magi) as a monotheistic religion. The Qur'an has mentioned the adherents of Zoroaster (Magian) together with the adherents of Judaism and Christianity in Surah (chapter) Al-Hajj: 17. Besides, some scholars have interpreted that the meaning of the word " صلوات in Surat al-Hajj verse 40 as a place of worship of the Magians (Al-Fairuzabadi, n.d.). The basic principles of Islam, such as monotheism, prophethood, and $m a^{\prime} a d^{l}$ (life after death) are also found in Magi. In addition, some of the basic principles of the Shiite sect such as justice were part of the noble values of humanity in Iran at that time. Some Islamic laws and rules were common for Magian with differences in quantity and quality. Respecting and glorifying religious leaders and public figures is common in Persian culture. This characteristic, along with the cultural and educational appropriateness for Persians, can be a supporting factor in the presence of the descendants of Imams from the Ahl al-Bayt of the Prophet in Persia.

Since examining all the beliefs that attracted the Ahl al-Bayt to migrate to Persia is impossible to do, this article focuses the discussion on three components namely: the Persian beliefs system of God, the resurrection, and justice and morality. The following section will discuss further related to the principles of Zoroaster (Magi) religious beliefs and their connection with Islamic teachings.

\section{Principles of the Divinity of pre-Islamic Persians}

Before the emergence of the Zoroastrian religion, the religion of people in Persia adhered to various teachings such as polytheism, paganism, and animism. Based on the contents of the Gathas (the oldest text of Zoroastrianism) a Zoroaster religious leader was called Zarathustra and called against the beliefs of polytheism and called upon the Persians to believe in One God named 'Ahura Mazda'. According to Gathas, Ahura Mazda is also known by other names such as Mazdaahura, Hormazd, Ahura, and Mazda. Ahura means leader, great, creator, God. While Mazda means wise. Regarding the meaning of these words, there are different opinions among the orientalists (Razi, 1383, p. 91).

According to Zarathustra, only Ahuramazda was worthy to worship (Pourdavoud, 1394, p. 135). Strength and majesty come from Ahuramazda. He is the One and Almighty Creator (Pourdavoud, 1394, pp. 129-130). He is All-Knowing (Pourdavoud, 1394, p. 113). He is the one who gives power. By looking at his expressions, he believes in one universal God who is Almighty and the Creator of all things. In other words, he believes in substantial monotheism and the monotheism of creation. It is the One God who has organised the universe, the God of the universe. In the inscriptions of King Darius and King Khashayarsah ${ }^{2}$, only Ahuramazda is stated as God. The one who has created the heavens, the earth, and human. The one who has created joy and happiness for mankind and has given the kingdom to Khashayarsah (Christensen, 1345, p. 63).

Zoroastrianism has the dualism principle. It is the belief that there are two opposing and competing forces, namely good and evil forces. In the tradition of Zoroastrianism, evil is represented by Angra Mainyu, while good is represented by Spenta Mainyu. Angra Mainyu means thought, character, and path of evil, which is also called Ahriman. Spenta Mainyu means thought, character, holy path, and goodness. Meanwhile, during pre-Islamic times those principles are considered as two opposite poles. ${ }^{3}$ Whereas in the teachings of Zoroaster in the Gathas, ${ }^{4}$ the two things are not considered as opposites to one another. This distortion was believed to be happened in the period of the Sasanian Dynasty by

\footnotetext{
${ }^{1} M a^{\prime} a d$ (escathology) means place or time of return. $M a^{\prime} a d^{\prime} s$ discussion explains the post-death life from barzah to the apocalypse and things related to it such as reckoning, heaven, hell etc.

${ }^{2}$ Names of Kings in ancient Persia

${ }^{3}$ If the concept of dualism of Zoroastrianism considers Yazdan and Ahriman to be two Gods who are on the same horizontal line, where Yazdan as the source of all evil and Ahriman as the source of all evil, then according to Islam it categorised as shirk, horizontal and substantial shirk (Zanjani, 1394, p. 55).

${ }^{4}$ Gathas is the oldest text of Zoroastrianism and is associated with Zoroaster.
} 
some scholars, and it was continued by the writers in the Islamic period. Subsequently, orientalists and Avestan scholars spread the belief and concept of dualism in the Zoroastrian religion (Razi, 1383, p. 90).

However, this principle of divinity in Zoroastrian differed significantly from that of Islam. According to the Islamic belief system, Ahuramazda was very different from Allah SWT. In Islam, God is One and the Creator of the universe and ruled the entire universe. While based on the Aryans, an ethnic Persian, Ahuramazda is juxtaposed with another god: Avesta, the helper of Lord Ahuramazda. In addition, the God of Islam has no material and physical appearance. Allah will never appear as a human or another creature. The human eyes cannot see or imagine God's existence as stated in Q.S. Al-An'am: 103. On the contrary, Ahuramazda was depicted as has a material existence, and his appearance can be seen in the form of the statue.

Another criticism attributed by Islam to the religion of Zarathustra is the concept of the divinity of Zoroastrianism related to the satanic creation as the source of evil beings in the universe. In the Islamic view, the devil has no role in the creation of anything. There is no creation of anything attributed to the devil. Based on Islamic teachings, the realm of the devil is located in the juristic area, not in the creation area. It means that the devil can only whisper the evil path to humans and invite them to sin, and has no role in the creation of the universe (Motahhari, 1390, p. 204).

The crucial critics directed to the concept of the divinity of the Zoroastrian religion is the purification of fire which triggers allegations of shirk (polytheism) against the worship of Zoroastrian adherents among Muslims. As a justification for the worship of the sacred fire of the Zoroastrians, some argue that it is similar to the Kaaba. Some said that Muslims praise the Kaaba as the Zoroastrians praise the fire (Moin, 1363, p. 138). In the Islamic view, the wisdom of standing facing the Kaaba for Muslims is to point in one direction during worship (shalat). In a sense, that the Muslim direction of prayer must be the same and not divided. It means to unified the direction to the place where Islam was first revealed (Motahhari, 1390, pp. 218-219).

\section{Principles of Justice and Morals}

In Zoroastrianism, justice is the main requirement of the kingdom, the main task of the ruler. If a government loses justice, it will lose its legitimacy and cannot continue its leadership. The central concept in Avesta is Arte or Ashe which means law and order. Truth versus lies covers all aspects of life. Living under the auspices of Ashe's care and justice will guide individuals and society to happiness. The law of Ahuramazda is the supreme law, and the king on behalf of Ahuramazda will enforce the law. Therefore, rulers must be careful to do things right. Most important of all is that justice should be served in all areas. A country will achieve prosperity through justice (Fazilat, 1381, pp. 79-80). This tradition is carried out to make the just rulers and enforce justice prominent and eternal in Persian history. Based on a hadith that attributed to the Prophet Muhammad, he said that one of the causes of the persistence of the Persian leadership period was because they held to justice tightly (Balkhi, 1374, p. 5).

Some scholars believed that Cyrus (d.539 BC) under the influence of Zoroastrianism, opposed the destruction of cities, banned murder, captivity, destruction of farmland, and looting of property (Saloor, 1340, p. 314). Therefore, the Persians called Cyrus a 'father'. The Greeks called him 'the leader of law enforcement and the Jews called him 'the Messiah and messenger of God' (Waters, 2004). One of the most important principles of Cyrus is the Great's Universal Declaration of Human Rights: freedom of religion, religious plurality, tolerance, and respect for customs and beliefs (Masod, 1388, pp. 73-74).

Based on the description above, Cyrus the Great accommodated a variety of different people from different cultures, languages, and races with a focus on morality and tolerance. All united towards the goal of the great ruler. The people cooperated and participated in advancing the goals of the empire. Officials from various departments follow up on government programmes with full coordination and consolidation. Respecting religious and local traditions, forgiving the enemy, responding to the complaints of lost people are commendable behaviours of Cyrus the Great that was unmatched in ancient times (Xenophon, 1388, pp. 229-235). Thus, referring to historical data and documents, as well as to the verses of the Qur'an, Torah, and the Bible, Cyrus the Great is the only one that has the most 
correct arguments to get the title of 'Dzulqarnain' (Alexander the Great). Allamah Tabathabai, Ayatullah Makarim Shirazi, Ayatullah Shani'i are contemporary scholars who consider that 'Dzulqarnain' is Cyrus the Great (Masod, 1388, p. 75).

Evidence of respect for the people by the kings and rulers in Persia until the end of the era of the Sasanian dynasty is very well preserved in the history of Persia. Ardashir I, the founder of the Sasanian dynasty, was a descendant of religious leaders who regarded the kingdom as a gift from God, upholding justice as a necessity of power and justice as the basis of all goodness. Therefore, he described his duty as a strenuous effort to uphold justice, spread and strengthen virtue, and develop the country (Mas'udi, 1433, pp. 251, 257). Ardashir's justice and morality became a role model for the next rulers like Khosrau Anushirvan (The Sassanian King).

The most ancient and holiest scriptures of Zoroastrian are the Avesta and the Gathas. Avesta originally consisted of twenty-one texts (books) that were divided into three parts (Pourdavoud, 1394, pp. 184-186). Vendidad is the name of the nineteenth book of Avesta which means law and doctrine, and the main source of Zoroastrian law either religious ritual or general civil law. It is also one of the most popular of the Zoroastrian religious theological and law that has had been interpreted in various languages including in Pahlavi (Mazdapour, 1384).

The three pillars of Zoroastrianism that are heavily emphasised in the Gathas and all parts of the Avesta are good thoughts (humata), good speech (huxta), and good behavior (hurashta). "Blessings on good thoughts, good words, and good behavior, which have been and will be done here or elsewhere, with our souls will continue to strive for good" (Pourdavoud, 1394, p. 257). These three principles are stages of the perfection of human morality. A Magian must organise his life based on these three principles, and under those rays can adorn oneself with all the qualities of malakut (noble) (Azargasht, 1372, pp. 156-157).

Amshaspand means eternal holiness which is the nature of Ahuramazda. Each of these qualities is described as the highest model of morality in the Zoroastrian religion. Vohumana, called Bahman in Persian, means good thoughts. Asha Vahishta, called Ordibehesht in Persian, means the best of honesty and chastity. A Zoroastrian must be a follower of honesty and truth and seek the best. Xshathra Vairya, called Shahrivar in Persian, means the ruler of the heavens. The authority and material power of this world must always reflect the power of God and the attributes of Ahuramazda so that kings and rulers can establish justice in human life.

Spenta Aramaitipure, called Esfandar Maz in Persian, means humility and patience. Haurvatat means maturity, perfection, and wholeness. In Persian, it is called Khordad which means physical and spiritual health and safety. It means if Zoroastrian has a character with the four attributes of God, he will reach perfection and the Haurvatat state. Amertat called Mordad or Amrdad in Persian means immortality. If a Zoroastrian has passed the fifth stage, he will arrive at the Amertat state. He will live eternally with God Ahuramazda, and his soul will be happy forever.

The texts about morality and jurisprudence in the Sasanian period and Zoroastrian include a series of advice such as the advice of Azarpa Mehr Sepandan, the advice of the sages to the Mazdisna, the instructions or treatises of the doctrines such as Vandidad, about what is proper and inappropriate and others. These treatises and advice were structured to regulate individual and social relations. Therefore, the texts are classified into two groups: first, the moral advice that needs to be followed. Second, the obligation laws that need to be carried out.

\section{Zarathustra's Concept of the Women}

Zarathustra's teaching regarding women and their relationship to men seemed overlapping. The relationship was hierarchical, with men as superior to women. Several works of literature mentioned the duties and boundaries that the women have to obey as stated in the moral teaching of Asha, which contains justice and independence (Ghaderi, 1384). Asha is one of the most important topics of morality and advice of the Sasanian period. Asha is essentially the one that ruled the universe and regulated the orbit of the sun and the changing of the seasons. It also guides human society in such a way to provide 
the means of worldly welfare and the happiness of the hereafter. Humans must obey this rule and exercise piety as the foundation of their lives (Boyce, 2000).

Independency means that everyone knows the duty and the limit attributed to it. No one should do the duty that is not assigned to him/her or do various duties or otherwise results in chaos. The independence and obligation of the people are to obey and not to interfere in the affairs of the rulers. While the task of the ruler is to lead and manage the affairs of the people. Therefore, the independence (khiskari) of women is not only moral teaching but also a doctrinal commandment that has also been emphasised in Pahlavi texts and narratives. However, when it comes to the affairs of women, it seemed very different in its application. For example, the queen should communicate with the husband regularly about what to think, say, and behave in the same way. Whatever kindness the husband says, she must do it and avoid opposing and hurting him. If the wife respects this teaching, she deserved to receive two hundred Dirhams from the husband's property in a year with the husband's approval.

Over time with the disappearance of the Zoroastrian religious literature in Alexander's invasion, Avesta interpretations and scholarly consensus supplemented the remaining texts (Mirfakhraei, 1367). Historical evidence shows Moghan's (Zoroastrian scholars) negative view of women as we read in Bundahes, one of the authentic Pahlavi books and one of the sources of research in ancient Persia. In this book found the statement about woman attributed to Ahuramazdā: "If I had found another vessel from which to produce man, I would never have created you [woman]"(Dadgi, 1369, p. 83)

The story of Jahi, the female devil in Avesta, showed the negative role of women. It was her who instigated Ahriman in the war with Ahuramazda and Amshasbandan. It was the kind of woman who encouraged Ahriman to commit evil and dragged him to confront Hormozd (creator of goodness and purity) (Razi, 1376, pp. 1534-1535).

Moghan considers the appearance of Dashtan (menstruation) as the imprint of Ahriman (demon) on women which causes menstruating women to be separated and send far from everyone and everything so that Satan can get out of them. This rule is repeated every month. Also, in the Sasanian era, the ritual of purification for women was very difficult and tiring. Women during menstruation and childbirth are considered unclean. The most serious defilement is stillbirth which means having a demon in the body. The ritual of bathing and purification in this case is very difficult and long. ${ }^{5}$

Moreover, women who have had a miscarriage must carry out the most difficult rituals. It is called the Brashnum ritual. The women should perform a nine-night bathing ritual guided by two priests. One of them must hold the dog's metal chain so that the dog's gaze can remove the unclean. Its ceremony should be conducted in a place that is barren and arid, with no water, fire, nor plants. It means that the people who perform rituals must stay away from Bahman creatures and good people (Pourdavoud, 1394, pp. 550-551, 571-572).

In the purification ceremony, cow urine sometimes is used as a substitute for water. Because of the difficulty in this ritual performance, the priests who lead the ceremony often charge the women a certain fee. The abuse of this teaching by the Zoroastrian priests became a factor of deviation in religion by the religious leaders during the Sasanian period. Based on this negative view of Moghan, Zoroastrian society does not treat women as human beings. Based on their human personality, women are objects that every man can enjoy. It was also stated in Vandidad that women were one type of offering or gift (Razi, 1376, p. 462).

Apart from the above-mentioned condition related to women, the husband has the right to give his only wife or one of his wives - the beloved one, to another man without her conducting any wrongdoing and without her consent (Christensen, 1345, p. 392). Furthermore, it was considered a crime and a sin when a man committing adultery with a married woman because it was against the law by taking another man's belonging. As a penalty for the deed, he had to pay three hundred Esters (currency) to the husband of the wife. In addition, to atone for his sin to himself, he had to go to Radan (the priest) and confess his sin. In contrast, the adulterous women, besides being considered to commit theft of their husband's property, should commit psychological sins. Based on the law of 
appropriateness and impropriety, she is considered a sinner who deserves death, also known as margarzan 'a worthy of death.' She should surrender her body to the priest and repents sincerely for the sins she has committed. The priest shall command her to work and do virtuous behaviour to erase her previous wrongdoing. Besides, under the authority of the Priest and guided by Asha (the truth), she may sentence to death (Mirfakhraei, 1367).

The establishment of different laws and verdicts of the same crimes between men and women were also regulated differently among the Zoroastrian scholars. All those regulations were based on the patriarchal system in this period. These regulations regarding the relationship between women and men in Zarathustra teachings are in contradiction with that of Islamic teaching. As stated in the Qur'an the basic nature of humans is loving and kind and supportive of the truth and justice (Q.S. AlInfithar:7). Therefore, there are no differences between all human beings regardless of gender, race, or nationality. All human beings are the same before Allah except for their righteous did (taqwa) (Q.S. AlHujurat: 13, Al-Hadid:25, An-Nisa:58, Al-Maidah:7).

Islamic justice is absolute and not relative (Motahhari, 1373, p. 317). In this case, moral relativity is also contrary to the universal and the basic teaching of Islam as the last religion. Morality contains a series of teachings and considers the basic principles of morals, education, and Islamic teaching (Hajj Mohammad, 1998). Justice is divided into two types, namely individual justice and social justice. Some scholars argue that the meaning of justice as stated in the Qur'an surah An-Nahl: 90 is social justice. It means that every member of the community must be treated properly. It is a social quality that every individual must do justice as a part of the community. Meanwhile, the state should maintain this justice through its regulation and policy (Tabataba'i, 1391, pp. 231-232).

According to Islamic teachings, Allah Almighty has created humans from one soul (Q.S. An-Nisa: 1) and the only measure of human glory and superiority is piety (Q.S. Al-Hujurat:13). Allah has order humans to seek their sustenance based on their full capacity (An-Nisa: 32). Islam respects the rights and freedoms of women like men. Islam has also forbidden husbands to remarry without his wife's permission and he is forbidden to do so if he is unable to do justice between his two wives (An-Nisa: 29). These glorious and comprehensive teaching of justice and morals in Islam, the preservation of human dignity and the high position of women in Islamic teachings in the Qur'an has attracted Persian society to embrace Islam. Especially so for the women who were tired of Moghan's oppression toward them and become the protectors of the clerical leaders of this new religion.

\section{Principles of Eschatology (the Life After Death)}

In Zoroastrian's belief system, the end of the material world is to reach the level of perfection which the Creator of the universe has determined. It is the time of the destruction of Ahriman (evil/demon) and also the good end of all beings into the new creation. In other words, all material beings since the beginning of the creation have been and continue to have a substantial innate melody to return to the original of their creation (Fazilat, 1381). This process is called Farshgar. ${ }^{6}$

In Islamic eschatology, this condition is called $m a^{\prime} a d$, which linguistically means return. Generally, $m a^{\prime} a d$ in the Qur'an means returning to Allah SWT. What happens on $m a^{\prime} a d$ Day or judgment day are classified into two parts. First, the current structure of the universe will be destroyed in a frightening and shocking process. The second, there will be calculating human deeds process in carrying out the obligation of worship to Allah. Thus, the person who is categorised as the wrongdoer who is opposed to the command of Allah will be separated from those who did righteous deeds who are obedient to Allah. Allah will take responsibility for human beings by calculating their conduct and grant for the justice of Allah (Q.S. Yunus: 7).

Differ from that of eschatological teaching in Islam, in the Zoroastrian texts, reckoning the good and bad deeds of human beings is not postponed until the end of time or doomsday. After death, the human soul will be separated from the body and goes directly either to heaven or hell depending on

\footnotetext{
${ }^{6}$ Farshgard means to bring the world to the perfection that existed at the beginning of creation and before Ahriman (the devil) invaded and entered it.

Fatemeh Sadat Alavi Aliabadi, Sayed Alireza Vaseil Persia, the Land of Shiite Faith: The Migration of Imam Ahl al-Bayt and the Encounter between Two Belief Systems in Persia
} 
their deed on earth. On Judgment Day, all beings, including the human soul and body, will be purified by a river of hot metal liquid to destroy all bad and dirty (Shaked, 1381, pp. 92-94).

The concept of eschatology in Islam is the time for calculating human deeds in the world. Meanwhile, Farshgard in Zoroastrian belief is a condition where the whole of nature is in the general range when all material and spiritual levels essentially display the image of healing. In this case, the human as representative of a microcosm (small universe) and the universe as a macrocosm (large universe) are all purified from wounds and impurities (Zaner, 1377).

The judgment day in Islamic teachings is a matter that only Allah knows the time of its occurrence. According to the Qur'an, it is the event that will happen very close (Q.S. An-Nahl: 77). Meanwhile, according to farshgard, it is an event that has been determined at the time of the creation of the universe (Shaked, 1381, p. 93).

Besides the differences between $m a^{\prime} a d$ and farshgard stated above, there are similarities between the two related to the role and condition of the earth. Ma'ad and farshgard, although each is related to the realm of the universe, both are events that occur which the earth as its axis $(\mathrm{Q} / \mathrm{S}$. Thaha: 105-106, Faranbagh Dadgi, 1369: 138). Besides, one of the similar beliefs between Muslims (Al-Baqarah: 28 \& 260, Al-Qamar: 7, Al-Hajj: 7, Al-Adiyat: 8 and others) and Zoroastrians (Fazilat, 1381) is the belief in the resurrection of the body, the belief in the calculation of deeds (Al-Anbiya: 47, Al-Mukminun 101-104, Al-A'raf: 98-Avesta, 1394, vol.1: 252), and the belief in reward and the torment of the hereafter (AliImran: 133, Az-Zumar: 73, Shad: 49-59, Ar-Ra'd: 23-Avesta, 1394, vol.1: 252). Those are the eschatological similarities between Islam and Zoroaster.

Generally, eschatology is the principal teachings in Islam and Zoroastrianism. There are three categories in Islam and Zoroaster related to eschatology, namely the possibility of its occurrence, the necessity of its occurrence, and how it occurs. The differences in the eschatological principle between the two lied in the fact that in Gathas no specific description is mentioned related to the resurrection of the dead or how the dead are raised. On the other hand, the Qur'an explains the possibility, the necessity, and the manner of the apocalypse (Shuraki \& Mohammad Jafari, 2015).

\section{Zoroastrian and Islam: Encountering Theological Belief Systems}

Islam arrived in Persia through the expansion of preaching of the Prophet Muhammad and in the era of the presence of the Imams of the Ahl al-Bayt. The Persians at that time found this religion had similarities in several aspects with that of their existing religion. Those aspects are related to the teachings and belief in the One True God, the belief in morality and justice, and eschatology. Those teachings have had attracted a lot of attention from the Persians. Besides, the similarities occurred in the Zoroastrian religion and Islam's three basic principles: to think, say, and behave righteously. Those teachings are stated in both scriptures of Islam, the Qur'an, and the Zoroastrian's Gathas.

In conclusion, Islam and Zoroaster agreed on certain basic principles. However, there are also several Zoroastrian's beliefs that have been distorted, contradict the teaching of Islam. For example, the interpretation related to the verse 'ashhabul $u k h d u d u$ ' (trench maker from Persia) in surah Al-Buruj. Another example is in the teaching of marrying a mahram as stated in Q.S. An-Nisa: 32 which Islam forbid the practice. In fact, In Zoroastrian, this practice was also condemned, but the evil desire of human lust has given its legitimacy (Ath-Thabari, 1999, p. 532). Other criticism also directed by Muslim Qur'anic exegete regarding the Zoroastrian ritual of a dead person based on the interpretation of the Qur'anic verse Surah Al-Mursalat: 25-26 and Surah Abasa: 21 (Ibn Ashur, n.d.). The concept of determinism and human ability to determine own destiny also responded in several Shiite exegeses because the Shiites also believe in the concept of intermediary position (amr bainal amrain) (S. Vaez, 1388, p. 362).

Based on the above description, this article showed that Islam is more open to the Zoroastrians rather than to other revealed religions like Jewish and Christian. One reason emerged that the other two religions, Jews and Christian, are more exclusive compared to that of Zoroastrians, as also has been 
stated in the Qur' an (Q.S. Al-Baqarah: 113). ${ }^{7}$ For this reason, the descendants of the Imam from the Ahl al-Bayt of the Prophet decided to migrate to Persia. In addition, various studies have reported profound differences among Islam, Judaism, and Christianity in the forms of the principles of Divinity, eschatology, justice, and morality. ${ }^{8}$ Despite the closeness of teachings between Islam and Zoroaster, the absence of discrimination of race, gender, and caste/social status in Islam add the attractions of Persians to understand Islamic teachings, especially Shiite teachings. It was also shown from the support of the people of Persia before Islam to participate in the resurrection of Mukhtar Tsaqafi to avenge the blood of Imam Hussein (grandson of the Prophet Muhammad) who was martyred in Karbala. ${ }^{9}$ Other historical evidence was found in the second half of the $2^{\text {nd }}$ century $\mathrm{AH}$ on the information related to the presence of hadith narrators from Shiite from various regions in Persia (Pakatchi, 1393, pp. 189-311).

The main mission of the descendants of the Imam from the Ahl al-Bayt of the Prophet who migrated to Persia is to spread Islam and prove the superiority of the teachings of the Ahl al-Bayt. It is narrated about the journey of Ali ibn Musa ar-Ridha to Persia in $201 \mathrm{H}$. Upon his arrival, he was welcomed by the people where he led the lively discussion about religious teachings in Islam. The people asked him about various issues and problems on religious matters. He also narrated several hadiths he learned from his great, great grandfather, the Prophet Muhammad (Ibnu Babawaeh, 1388, p. 467).

It is reported that Imam Ali ar-Ridha has had narrated about 2290 hadiths during his stay in Persia (Khani Moghadam \& Zahedi, 1394). The content of the hadith is mostly related to the information of the Imams, their lives, and their role in spreading Islam (about 1459 themes) (Ghotbi, Hadavi, Akbar Rahnama, \& Baghani, 2014). For example, the hadith that consider of 'golden chain' (silsilah adz-dzahab) was narrated in Naishabur. Imam Ali Ridha even explained in detail the genealogy of Imams through to the Prophet Muhammad. The most important issues that arose in the dialogue were about faith and laws (Thabarsi, 1403, pp. 369-499). The important results of the dialogue were to show the excellence

\footnotetext{
${ }^{7}$ Exclusivism in a specific meaning claims that all truths belong to one religion and therefore, other religions do not obtain those truths. Exclusivism has two theoretical or ideological interpretations and the identification of the path of salvation. Due to exclusivism, ideologically or theoretically, the teachings of a religion are completely true and the teachings of other religions are wrong as long as they are contrary to the religion. The way of salvation exists only in one particular religion (Patterson, 1379, p. 402).

Some argue that Islam has strongly supported exclusivism over other major religions in the world historically (Lewis, 1993, p. 175). In fact, the meaning and purpose of exclusivism in the Islamic view is very different from the claims found in Jews and Christians. Islam regards itself as the last religion perfecting the religion of Judaism and Christianity. For example, if a Jew claims exclusivism, it means that only Judaism is the true religion, and other religions are false. When Islam claims exclusivism means the perfect and comprehend religion of the previous revealed religion, because Islam did not denied Judaism and Christianity, as Islam also believed in both Prophet, Moses and Isa (Jesus). For this reason, Islam has introduced itself as a perfect model of Judaism and Christianity. Thus, in other word, exclusivism in that specific sense has no meaning in Islam. Based on the Qur'an, the teachings brought by Prophet Adam as to Prophet Muhammad are one (Ali-Imran: 19 \& 67).

${ }^{8}$ Although in all three religions Judaism, Christianity and Islam believe in monotheism, there are differences in the essence and concept of monotheism. The Qur'an has described God as an indefinite Being, not limited by space and time, and having no allies (Al-A'raf: 190 \& Al-An'am: 19). But monotheism in Judaism is a kind of monotheism in which some resemble God. Similarly, monotheism in Christianity has the concept of the Trinity and multiple Gods. The three religions of Judaism, Christianity and Islam agree on the basic principles of eschatology and life after death. The difference lies in where Jews consider paradise reserved only for Jews, while in the Qur'an sets the benchmark for entering heaven or hell one's piety and deeds are not race and social status. While Christians believe that heaven is reserved for those who accept that the Prophet Jesus is the Son of God (B. Vaez \& Ilvari, 2012).

${ }^{9}$ In most, Shiite uprisings after Ashura, two factors have attracted Iranians: 1 . The oppression of the Ahl alBayt family 2. The humiliation of the Mawali (Iranians) by the Umayyads ( The Umayyads considered the Arab race to be the superior race and said: Because th e Prophet of Islam originated from the Arabs, then the Arabs are superior to other peoples, and among the Arabs, the Quraysh are superior to others. According to this policy, the Arabs were preferred to the "non-Arabs" in all respects.)
} 
of knowledge, legitimacy, and competence of Imam Ali ar-Ridha as well as the excellence and perfection of Islamic teachings (Khani Moghadam \& Zahedi, 1394).

There are about 364 narrators of the hadith of Imam Ridha and 207 of them are his companions of which 46 of them are Iranians (Atharidi al-Khabusyani, 1406, pp. 510-566). One of the descendants of the Imam from the Ahl al-Bayt of the Prophet who migrated to Persia is Fatimah Maksumah. She is the sister of Imam Ali ar-Ridha who is also a narrator of the hadith. Based on the books of hadith, she is one of the narrators of hadith mentioned in the hadith chains. Hadiths narrated from Fatimah Maksumah related to love for the Ahl al-Bayt, hadith ghadir (the event of the appointment of Imam Ali bin Talib as the successor of the Prophet Muhammad in Ghadir Khum after Hajj Wada- the last pilgrim of the Prophet) and hadith manzilah (manzilah or the position of Ali bin Abi Talib on the side of the Prophet Muhammad was similar to the position of Haron to the Prophet Moses and many others. Her role in the hadith narration is important for she was categorised among the companions and narrators as one of the hadith narrators without intermediaries (received the hadith from the first hand).

For example, the hadith of Fathimiyat, named after the narrators of this hadith most of are Fatimah by name. The hadith was narrated from Fatimah bint Hussein Ridhawi, narrated from Fatimah bint Abdullah Alawi, narrated from Fatimah bint Musa Mabarqa, narrated from Fatimah bint Ali ar-Ridha, narrated from Fatimah bint Musa bin Jakfar, narrated from Fatimah bint Jakfar ash-Shadiq, narrated from Fatimah bint Muhammad al-Baqir, narrated from Fatimah bint Ali Zainal Abidin, narrated from Fatimah bint Hussein, narrated from Zainab bint Ali, narrated from Fatimah bint Rasulullah saw that Rasulullah saw said, "And behold! He who dies with love of the family of Muhammad is a martyr" (Zamakhsyari, n.d.).

The above-mentioned hadith informs the Muslim to love the Ahl al-Bayt of the Prophet, and whoever died in the state of loving the Ahl al-Bayt is considered a martyr (shahid) which is a very rewarding death. During the period of the Abbasid dynasty, the rulers severely oppressed the followers and lovers of the Ahl al-Bayt of the Prophet by terrorising, imprisoning, and torturing them. It was the work of Fatimah Maksumah and other hadith narrators to initiate the movement against oppression. In the end, Imam Ali ar-Ridha and his followers decided to migrate to Persia and spread the Shiite teachings.

The descendants of the Imams of the Ahl al-Bayt of the Prophet also played a major role in spreading the Shiite sect in Persia by migrating to various parts of Persia and sending reports of what they had seen and heard about their noble ancestors. For instance, Yahya ibn Zaid ibn Ali ibn Hussein migrated to Persia in 121-122 H after the martyrdom of his father, Zaid ibn Ali ibn Hussein. One of the valuable legacies of Zaid bin Ali is Shahihah Sajjadiyah (a collection of prayers from Imam Ali Zainal Abidin/the fourth Shiite Imam). Another version of this book is in the hands of Imam Ja'far Shadiq/the sixth Shiite Imam, and now in the hands of Imam Mahdi. The book is so important for the followers of the Ahl al-Bayt of the Prophet and it is also called 'the chief of the Islamic books 'The Psalms of the family of the Prophet Muhammad saw' and 'The Gospel of the Ahl al-Bayt of the Prophet saw'.

There are many authentic Shiite hadith narrated by the descendants of Imams from the Ahl al-Bayt of the Prophet who migrated to Persia for the next generation. For example, in the book of Al-Kafi, 208 hadiths have been narrated by fifty-two descendants of Imams from the Ahl al-Bayt of the Prophet, and thirty-nine of them have clear lineage, while the others are written as Alawi (Hosseini, 1387). A considerable number of the descendants of the Imams from the Ahl al-Bayt of the Prophet saw who were also hadith narrators have had lived in Persia. They migrated to Persia either voluntarily or forcefully as a way of exile from the oppressed ruler in the country of origin.

\section{The Interconnectedness of Migration, Religion, and Identity}

The theory of migration is usually focused on ethnicity and nationality. Less study on migration directed to theological-missionary purposes. The description in this article intersects very closely between migration and the spreading of theological beliefs. The article contextualising the acceptance of the new religion - Islam - by the people in the mainland, Persia. 
This article also explains the reason for migrating from the origin country, apart from the missionary spreading the Islamic teaching as the main reason, security is the other important reason for the Ahl al-Bayt to migrate. Ahl al-Bayt of the Prophet Muhammad at the second Hijri experienced oppression and was threatened by the ruling party: the Umayyad and Abbasid dynasty.

In this case, the migration of the Ahl al-Bayt to Persia (Iran) certainly changing the religious landscape in the mainland. It affected and transformed the existing belief system, Zoroastrian, in the community to Islam which was brought by the Imams and become adhered to by the majority of the people in Persia. Thus, this article confirms the conception formulated by Nagy (Nagy, 2016, p. 39) on the intradisciplinary methodology of migration namely, migration as a locus theologicus and migration as a context. This article has provided both aspects presenting the experience of the Imam Ahl al-Bayt migrating to Persia and how they establishing their identity as a Shiite sect of Islam. Nowadays, Persia (now Iran) is well known as a land of Shiite adherents.

\section{Conclusion}

This article presented the background of the historical acceptance of the divinity principle, the principle of eschatology, the principle of justice and morality in pre-Islamic Persian society, and its continuation to the era of the Prophet Muhammad's mission. This article also examined some of the extreme distortions and beliefs that occurred in Persian society and Islamic society at that time.

Iranian society has known a new religion since the first century AH. It is a religion that has many similarities in the principles of the oneness of God, the principles of eschatology, and the principles of justice and morality. The other similarities are related to a belief in three basic principles: to think, to say, and to behave righteously and no racial, gender, and caste discrimination. Those factors have encouraged Persians to understand the teachings of Islam and respect its leaders.

Some descendants of the Imam of the Ahl al-Bayt of the Prophet have migrated to various parts of Persia voluntarily such as Ali ibn Muhammad Baqir. Some did under pressure such as Ali ibn Musa ar-Ridha who had traveled to Merv and had opened rooms for study and dialogue with leaders of various sects and religions, especially Zoroaster. It has caused the Shiite dialogue to grow rapidly so that the illegal tomb of Fatimah Maksumah in Qom turned into a Shiite centre in Iran. As a result, the descendants of the Imams from the Ahl al-Bayt of the Prophet also continued the mission of the Imams and spread the teachings of Islam more widely across Persia. They chose Persia as a country that is ready to accept Islamic preaching as well as suitable as a safe place away from the oppressed ruler in their country of origin.

\section{References}

Al-Fairuzabadi, A. T. bin Y. (n.d.). Tanwir al-Miqbas min Tafsir Ibn 'Abbs. Beirut: Dar al-Fikr.

Ath-Thabari, M. bin J. (1999). Tafsiruth Thabari al-Musamma Jami'ul Bayan fi Ta'wilil Quran. Beirut: Daarul Kutubil Ilmiyah.

Atharidi al-Khabusyani, asy-S. A. (1406). Musna al-Imam ar-Ridha. Masyhad: Al-Mu'tamar al-Alami al-Imam arRidha.

Azargasht, A. (1372). Marasemi Mazhab va Adabi Zoroastyan. Teheran: Forouhar.

Balkhi, I. (1374). Fars Name: Bar Asase Matne Musahih Lestring va Nicholson. Shiraz: Bunyad Fars Shenasi.

Boyce, M. (2000). Zoroastrians: Their Religious Beliefs and Practices. London: Routledge.

Christensen, A. (1345). Mazdaparaste dar Iran Ghadem: Mulahazatie darbare Ghadimitaren Ohoud Oyeene Zarthosty va Tahgheeghate dar Bab Kish Zarthosty Iran Bastan (Z. Safa, trans.). Teheran: Daneshgah.

Dadgi, F. (1369). Bandesh (M. Bahar, trans.). Teheran: Toos.

Fazilat, F. (Trans.). (1381). Kitab Sevom Dinkrd, Darsnameye Din Mazdaei. Teheran: Farhangge Dehkhoda.

Ghaderi, H.-S. F. (1384). Ghudrat va Jenseyat dar Akhlagh va Fegheh Zoroast doure Sasani. Oloume Insanei Daneshgah Zahra, 55(1), 139-166.

Ghotbi, S., Hadavi, A., Akbar Rahnama, \& Baghani, F. (2014). Tahleeli Abad va Moalifahae Eteghadei Sabake Zendegi Eslami dan Amozehae Razavi. Motaleat Marefatei Dar Daneshgah Eslami, 18(60), 435-450.

Hajj Mohammad, E. (1998). Nisbiyate Akhlagh az Didgahe Shaheed Motahari. Keyhan Andisheh, 81(1), 39-58.

Hosseini, S. H. (1387). Emamzadegan Rawi dar Al-Kafi. Tsiqqatul Islam Kulai, 103-133. 
Ibn Ashur, M. T. (n.d.). Tafsirul Tahrir wa Tanwir al-Ma'ruf Bi Tafsiri Ibni Asyur. Beirut: Muasasah at-Tarikh. Ibnu Babawaeh, M. bin A. (1388). Uyun Akhbar ar-Ridha (M. T. A. N. Isfahani, trans.). Qom: Alamdar.

Khani Moghadam, M., \& Zahedi, A. R. (1394). Tabyine Nazariye Mohajerat Emam Reza va Emam Zadegan dar Rastaye Sonate Ilahi Estibdal. Farhangge Razavi, (10), 43-74. Retrieved from https://www.noormags.ir/view/fa/articlepage/1103266

Lewis, B. (1993). Islam and The West. New York: Oxford University Press.

Mas'udi, A. bin H. (1433). Muruju adz-Dzahabi wa Ma'adinul Jauhar (M. M. Qamihah, ed.). Beirut: Daarul Kutub alIlmiyah.

Masod, M. (1388). Zartosht: Koroush va Hoghoughe Bashar. Teheran: Kaktoos.

Mazdapour, K. (1384). Mirase Zartosht, Payamovar Rasti/Goft va Gou. Haft Aseman, (25), 9-24.

Mirfakhraei, M. (Trans.). (1367). Revayate Pahlavi Matni be Zabani Parsi Miyaneh (Pahlavi Sasani). Teheran: Moasese Motaleat va Tahgheghat Farhanggi.

Moin, M. (1363). Mazdizna va Adabe Parsi. Teheran: Moasese Intesharate va Cap Daneshgah Teheran.

Motahhari, M. (1373). Islam va Moghtazeyate Zaman. Teheran: Sadra.

Motahhari, M. (1390). Mutual Services between Islam and Iran. Teheran: Sadra.

Nagy, D. (2016). Minding Methodology: Theology-Missiology and Migration Studies. In M. Frederiks \& D. Nagy (Eds.), Religion, Migration and Identity (pp. 30-59). Leiden: Brill. https://doi.org/10.1163/9789004326156_004

Nasr, S. H., \& Mutahhari, M. (1975). The Religious Sciences. In R. N. Frye (Ed.), The Cambridge History of Iran (pp. 464-480). Cambridge University Press. https://doi.org/10.1017/CHOL9780521200936.016

Pakatchi, A. (1393). Shi'a dar Iran: Tarikhe Jame Iran. Teheran: Markaze Dairatul Maarif Buzurge Islamee.

Patterson, M. (1379). Aghl va Eteghade Deeni (E. S. Ahmad Naraghi, trans.). Teheran: Tarhnou.

Pourdavoud, E. (Ed.). (1394). Avesta. Teheran: Negah.

Razi, H. (1376). Vendidad. Teheran: Fikre Rouz.

Razi, H. (1383). Zoroast: Peyambare Iran Bastan. Teheran: Bahjat.

Saloor, S. (1340). Bunyad Shahanshahi Iran. Teheran: Ighbal.

Shaked, S. (1381). Az Iran Zoroasty ta Islam; Motaleat darbare Tareekhi Din va Tamashae Farhanggei. Pasal Ke-9 (M. Saqebfar, trans.). Teheran: Ghoghnoos.

Shuraki, S. M. H., \& Mohammad Jafari. (2015). Baresiye Tatbighie Emkan, kaifiyat, va Zarorate Maad dar Dine Eslam va Zoroast. Marefate Adyan, 6(4), 25-46.

Tabataba'i, M. H. (1391). Al-Mizan fi Tafsiril Quran. Beirut: Muasasatul A'lami lil Mathbua'at.

Tabataba'i, M. H. (2009). Barrasi-ha-yi Islami [Islamic Investigations]. Qom: Islamic Propagation Office.

Thabarsi, A. bin A. (1403). Al-Ihtijaj ala Ahlil Lujaj. Masyhad: Murthadha.

Vaez, B., \& Ilvari, R. K. (2012). Tabyine Tatbighi Mabani Nazari, Shar'i va Akhlaghi Islam, Yahodiyat va Masehiyat. Journal of Quranic Knowledge, 3(9), 67-98.

Vaez, S. (1388). Yad Kardhae Din Zarthost dar Tafasir Qoran Kareem. Mashad: Shamlou.

Waters, M. (2004). Cyrus and the Achaemenids. Iran, 42(1), 91-102. https://doi.org/10.1080/05786967.2004.11834648

Xenophon. (1388). Kouresh Name (R. Mashayehi, trans.). Teheran: Sharkat Entisharate Ilmi va Farhanggi.

Zamakhsyari, M. bin U. (n.d.). Al-Kasyaf an Haqaiq Ghawamidhit Tanzil wa Uyunil Aqawil fi Wujuhit Ta'wil (M. H. Ahmad, ed.). Beirut: Daarul Kitab Al-Arabi.

Zaner, R. C. (1377). Taalime Moghan (F. Badraei, trans.). Teheran: Toos.

Zanjani, M. E. H. (1394). Miyare Shirk dar Quran (A. Mojtahedi, trans.). Qom: Bostane Ketab.

Zarrīnkūb, A. (1993). Pìr-e ganje dar Jost-o-jū-ye nākojā-ābād. Teheran: Soxan.

(C) 2021 by the authors. Submitted for possible open access publication under the terms and conditions of the Creative Commons Attribution (CC BY SA) license (https://creativecommons.org/licenses/by-sa/3.0/). 